\title{
CORPORATE GOVERNANCE AND CORPORATE SOCIAL RESPONSIBILITY DISCLOSURE: EVIDENCE FROM SAUDI ARABIA
}

Murya Habbash King Khalid University, Saudi Arabia murya@hotmail.com

\section{ABSTRACT}

Purpose: This study aims to discover the Corporate Social Responsibility (CSR) disclosure practices and the potential influence of Corporate Governance (CG), ownership structure, and corporate characteristics, in an emerging Arab country, Saudi Arabia. This study extends the extant literature by investigating the drivers of CSR disclosure in a country that lacks research in this area. Methodology: This study examines 267 annual reports of Saudi non-financial-listed firms during 2007- 2011 using manual content and multiple regression analyses and a checklist of 17 CSR disclosure items based on ISO 26000. Findings: The analysis finds that the CSR disclosure average is $24 \%$, higher than $14.61 \%$ and $16 \%$ found by Al-Janadi et al. (2013) and Macarulla and Talalweh (2012) for two Saudi samples during 2006-2007 and during 2008, respectively. This improvement may be due to the application of Saudi CG code in 2007. The analysis also shows that government and family ownership, firm size, and firm age are positive determinants of CSR disclosure, firm leverage is a negative determinant, while effective AC, board independence, role duality, institutional ownership, firm profitability, and industry type are found not to be determinants of CSR disclosure. Originality/value: This study is important because it uses agency theory to ascertain the influence of specific board characteristics and ownership structures on disclosure. As a result it provides important implications for CG regulators and different stakeholders and provides an evaluation of the recently applied Saudi CG code from CSR disclosure perspective.

Keywords: Corporate Social Responsibility, Corporate Governance, Ownership Structure, Content Analysis, Saudi Arabia. 